\title{
On the theory of post-Communist economic transition to market
}

\section{Post-Communist economic transition}

\author{
Vladimer Papava \\ Georgian Foundation for Strategic and International Studies, Tbilisi, Georgia
}

\begin{abstract}
Purpose - The paper investigates the utility of economic theory for post-Communist economic transformation. It serves to explain the main reasons for market reform failure in different post-Communist countries.

Design/methodology/approach - A literature review suggests that after the collapse of the Communist system there was no economic theory of transition to market. Whenever one considers the transition of post-Communist economies to a market system (which, in fact, is nothing but post-Communist transition to capitalist economies), it has to be placed on record, as this kind of transition has no precedent in history.

Findings - The main mistake of gradualists stems from their overlooking some very important conditions for successful transition: political guarantees and internal assets for reforms. And the success of shock therapy rests on the paradox, "the worse, the better".

Originality/value - There is as yet no special economic theory of post-Communist transformation and it is just developing. This paper helps one to understand the main features of shock therapy and gradualism for designing the framework of such a theory. It is geared towards researchers and students interested in the theoretical aspects of the post-Communist economic transition to markets.
\end{abstract}

Keywords Economic change, Marxist economics, Capitalist systems

Paper type Literature review

\section{Whither economic theory?}

Professor Igor Birman, the famous Russian economist who emigrated from the USSR many years ago, once noted that capitalism had been developing for many centuries and this process had never depended on educated or uneducated economists, their advice and recipes (Birman, 1996, p. 521). Although this assertion is not unquestionable at all, in principle, it alludes to that historical phase in the development of economic science when it (science) was nothing but a mere reflection of economic praxis.

Economic science has a long history, but it was not always prepared to give right and timely answers to all topical questions that praxis would raise. Nevertheless, as a rule, economic science would manage to "catch up" in a few years stimulating thereby a search for new solutions to practical issues of economic growth. The rise and development of Keynesianism is one of the most remarkable examples in support of this assumption. Despite this, leading economists in the West tend to exaggerate the issue of the crisis of economic thought which, in their opinion, consists in its incapacity to suggest right solutions to the problems and predict the future of capitalist economy (Heilbroner and Milberg, 1996).

The collapse of the Communist regime in East Europe and the former USSR and an almost concurrent disintegration of the latter resulting in the emergence of 15 newly independent states gave rise to substantially new problems, no solution to which could be confined to any of those classical schemes that were elaborated by economic science during the whole period of its existence (Nove, 1993).

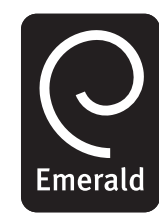

International Journal of Social Economics Vol. 32 No. 1/2, 2005 pp. $77-97$

(C) Emerald Group Publishing Limited 0306-8293 DOI 10.1108/03068290510575658 
IJSE

$32,1 / 2$

78
The transformation of Communist-style governmental institutions into market-based ones by itself is a very difficult task (Nunberg, 1999). In the countries that emerged as a result of the disintegration of the former federal states (such as the former USSR, Yugoslavia and Czechoslovakia) and that are not successors of the latter, the process of transition from the Communist-oriented economic system to market economy is further aggravated by a need to lay economic, but not merely economic, foundations for one's own statehood (Balcerowicz, 1995, p. 146; Milanovic, 1998, p. 3; Papava, 1996a, p. 252). In this context, by far "easier" looks the challenge that the former German Democratic Republic had to deal with, as the transition to market in this country was preceded by the unification of two German states (e.g. Derlien, 1999).

This process belongs to a group of the most significant events of the end of the twentieth century (Stiglitz, 1992, p. 137) and could be regarded as a global process of transition to market economy (Berend, 1994), whose impact on the development of economic thought could be compared with such events as the overcoming of the Great Depression of the 1930s (Avtonomov, 1996, p. 11), or the reconstruction of Europe after the end of the Second World War. As John Kenneth Galbraith points out, the said process is on a par with both world wars, as one of the three greatest historical events that the twentieth century is remarkable for (Inozemtsev, 1998, p. 7). It is not by accident that referring to the process of post-Communist transformation some economists have used the word "refolution" which is formed by the combination of the words "reform" and "revolution" (Goldstone, 2001, p. 117).

In a number of works (e.g. Andor and Summers, 1998; Kuzin, 1994), the problems of transition to market economy are considered in the light of and by analogy with the so-called "economic miracle" approach (Petrakov, 1998, p. 1990). (In the Georgian context, see (Petukhov, 1999).) The practice of evaluating successful applications of market mechanisms by using language like "economic miracle" gained in popularity especially with respect to the countries of East Asia (World Bank, 1993). However, the financial crisis of the end of the twentieth century that had shaken those economies up drastically reduced reasons which could justify the use of the word "miracle" in an economic discourse (Claessens and Glaessner, 1997; Weder, 2001).

That the modern economic theory is still unable to give exhaustive and theoretically justified answers to many important questions relating to the transition to market economy has been recognised by many leading economists of our times (e.g. Becker and Becker, 1997, p. 259; Stiglitz, 1996, p. 3). It might be stated without reservation that there is no economic theory of transition at all (Bertenev, 1996, p. 301; Papava, 2000). Birman (1996, p. 521) in his traditionally radical and, therefore, debatable style has asserted that economic theory reaffirmed its "convincing impotence" in dealing with the problems of transition to market economy.

It must be emphasised that from the standpoint of western economists even the problems of centrally planned development, not to mention those of transition to market, have always been considered as a temporary deviation from the generally accepted capitalist norm, for which reason thinking of transitory problems to them is nothing but a waste of time (Aukutsionek, 1996, p. 11). Nevertheless, the world's many well-known economists believe that since the early 1990s transition to market economy has become a key subject matter of economic research (Galbraith, 1992, p. 46), encouraging economists to review the problems of economic theory itself in the light of post-Socialist development (Buchanan, 1992). 
The first comprehensive textbooks of transition to market have already been published. Their authors come from both economies in transition and western developed nations (e.g. Abalkin, 1997; Belokrylova, 2002; Buzgalin, 1994; Geiger, 1992; Nikolaeva, 2001; Papava, 2002b).

\section{Post-Communist economic transition}

\section{On the transformation terminology}

Before continuing the discussion, it would be advisable to touch on some terminological issues. Specifically, referring to the post-Communist economies it is common to use expressions like "economy in transition" or "transitional economy" which are very vague by their nature, as it is not clear what kind of "transition" we are talking about. Although in the modern world it is transition to market economy that usually takes place, but by its nature this process is not a homogeneous one as economists have set apart two types of transitional economy - the traditional and the new ones: while the former is typical of tropical Africa and South Asia, the latter is more widespread in East Europe, the former USSR, some Latin American countries and China (Geiger, 1992, Ch. 1). It must also be noted that according to generally accepted definition "economies in transition" include just the countries of East Europe, former Soviet republics, China and Mongolia, although there are multiple countries across the globe (up to 30 of these in Africa alone) that are at the stage of transition from central planning to free market (Yarbrough and Yarbrough, 1997, p. 469).

The world history of the twentieth century knows such occurrences as the transition from capitalism to socialism (Bukharin, 1990, pp. 81-207) and then to communism (Kanth, 1997, pp. 211-25; Kornai, 1992, pp. 26-30; O’Brien, 1989, pp. 6-13, 23-8;); transition from capitalism to post-industrial, post-economic society (Bell, 1976; Inozemtsev, 1995, 1998); transition from modern capitalism to socialism (Brown, 1995, pp. 334-56; Buzgalin, 1994, pp. 23-32); transition from Stalinism to the socialist market economy (Nolan, 1995); and transition to drastic growth of production in the USA (Feldstein, 1980). As Drucker points out, today mankind is in the process of transition to a global economic system (Inozemtsev, 1998, p. 6) and is on the verge of the formation of post-Communist society (Drucker, 1993). According to Galbraith (1998, pp. 209-16), ongoing transition leads to an "affluent society".

In the 1990s, with the upcoming of the third millennium, the issues of cyberspace, cybereconomy and a sovereign individual in it were raised (Davidson and Rees-Mogg, 1998, pp. 11-39). It must be noted that practically all more or less serious economic developments observed in different regions and parts of the planet could be reviewed in the context of the world's universal economic transition (Hinshaw, 1996).

Belarus is the most apparent example of reversion from market to a central planning economy (Antachak et al., 2001).

Balcerowicz (1995, p. 145) suggested the following classification of historical "transitions":

- Classical transition that implies the process of expanding democracy in leading capitalist nations in 1860-1920.

- Neoclassical transition which was reflected in democratic developments after the Second World War (in West Germany, Italy and Japan in the 1940s; in Spain and Portugal in the 1970s; in some Latin American countries in the 1970s and 1980s; and in South Korea and Taiwan in the 1980s). 
IJSE

$32,1 / 2$

\section{0}

- Market-oriented reforms in non-Communist countries (in West Germany and some other western nations after the Second World War; in South Korea and Taiwan in the early 1960s; in Chile in the 1970s; in Turkey and Mexico in the 1980s; and in Argentina in the 1990s).

- Asian scenario of post-Communist transition (China in the late 1970s and Vietnam in the late 1980s).

From the standpoint of the "welfare state" the whole world could be regarded as one that undergoes the process of transition to that direction (Esping-Andersen, 1997).

In the light of developments that have resulted in the shaping up of a "New World Order" the meaning of the term "transition" has expanded to connote a set of strategies which enables the society to define and achieve the given order with minimum losses (Calkins and Vezina, 1996, p. 311).

It is useless to look for a general definition of the terms "economy in transition" and "transitional economy", as it cannot give us anything either in theoretical, or (especially) in practical senses.

A good example of the general approach to the process of transition, in general, and "transitional period", in particular, consists in the definition of it as "a period of time during which certain historical choice has to be made” (Rakitskaya, 1996, p. 87). It must be noted, however, that as the author of this definition remarks no "transitional period" could be in place if the choice is self-evident (Rakitskaya, 1996, p. 87).

According to one of the many ambiguous definitions of "transitional economy", it is a status between any two psychologically and theoretically opposite regulatory approaches, which are separated from each other by systematic or shocking conversion and which, in turn, differ from each other by powerfulness and duration (Kuznetsov, 1994, pp. 5-6). Another definition of "transitional period" or "transitional economy" says that it embraces both transition to a certain normal and balanced development status and a switch from one sustainable and balanced mode to another (Basilia et al., 2001, p. 93).

Another general approach consists in reconsidering the "process of transition" in the light of the "catastrophe theory". Specifically, such "processes", in a sense, are typical of a transition from one social/economic organisation to another, which can be referred to as a system transformation and, in a broader sense, any kind of system modification (Shurgalina, 1997, pp. 66-7).

One more example of the general approach to the "process of transition" is based on "institutional analysis of the evolution of transition to development" applied in different countries (Intriligator et al., 1999).

It is obvious, therefore, that no generally accepted definition of "transitional period" has been developed yet (Berezin, 1999, p. 253; Papava, 2000).

Based on all the above-described approaches one can conclude that whenever discussion is specifically about the transition of post-Communist economies to the market system (which, in fact, is nothing but post-Communist transition to capitalist economy) or, as Galbraith (1996, p. 101) would say, "to something approaching a market economy", it has to be placed on record, as this kind of transition has no analogy in history (Campbell, 1991, p. 227).

To exhaust the subject of terminology, it must also be noted that out of these two terms - "post-Socialist" and " post-Communist" - we would recommend to give 
priority to the latter as it denotes development orientation of relevant nations before their transition to market economy (Menshikov, 1996, pp. 17-22). It is also important to note that debates over the definition of the word "socialism" could not be considered concluded (Balcerowicz, 1995, pp. 19-27), as scholars tend to distinguish between Marxist, Soviet, Chinese, Yugoslavian and African models of socialism (Brown, 1995, pp. 181-286). Furthermore, there have been suggestions to set apart so-called "Afro-Asian Socialism" (Nafziger, 1997, p. 541); if you add to this "Fascist" (von Mises, 1981, pp. 363-8) (especially as there is the substantial difference between post-Fascist

Post-Communist economic transition

81 and post-Communist models of transition to market economy (Olson, 1995, pp. 53-4)), "Islamic" (Ignatenko, 1988, pp. 130-2) and "Swedish" socialisms, vagueness of the word "post-Socialist" becomes more than apparent. Besides, according to some scholars, the system that was established in the former USSR was by no means "socialist", but rather "pseudo-socialist" (Mikulskiy, 1999, p. 8) or "quasi-socialist" (Simonia, 1999, p. 14), not to mention estimations like "state monopolistic feudalism" used referring to it (Papava, 1995).

Sociologists have repeatedly noted that whenever the nature of certain society is not completely discerned, to avoid confusions, they tend to add to it the prefix "post" (like in words "post-industrial", "post-economic", "post-Socialist", "post-Soviet”, etc.). In this connection, outstanding are the works by Balcerowicz who prefers to replace the ambiguous terms like "post-Communist" and "post-Socialist" with a more understandable word "capitalist" (Papava, 2002a, p. 5).

Like socialism, capitalism by its nature is not homogenous. That model of capitalism that is shaping up after the downfall of the Communist regimes is significantly different from its American, European or Japanese counterparts. This allows us to introduce the term "post-Communist capitalism" (Papava, 2002b).

\section{Two ways of post-Communist transformation}

The practical uselessness of many classical theoretical schemes of transition to market economy resulted in the fact that in many countries this extremely sophisticated process was initiated and conducted in a wrong way.

Among the first consultants that arrived from the West to provide advisory services to the reformers in the post-Communist states, apart from the representatives of the International Monetary Fund (IMF) and World Bank, as a rule, were independent experts, not to mention occasional trippers and charlatans. At best, they were armed with some knowledge of economic theory and/or some experience in successful reforms implemented in Latin America, Asia and Africa (Adams and Brock, 1993, p. XIII). Birman (1996, p. 522), in his traditionally sardonic style, remarks that the reason for the mass departure of economists from the West was that nobody listened to them in their own homelands. As a rule, their advice was limited to general statements of the advantages of and the need for fastest transition to market economy (Stiglitz, 1996, p. 3).

Today, owing to quite inclusive empirical data, it has become possible to develop original scientific works about post-Communist transformation containing quite serious theoretical generalisations. Based on this, both practising reformers and economic theorists are divided into two major groups: the first one consists of the supporters of "shock" in economic reforms; the other one is composed of "gradualists". Each group has been established as one of the two key trends of the post-Communist transformation (e.g. Bogomolov, 1998, pp. 49-52; Boźyk, 1999; Hoen, 1999). 
IJSE

$32,1 / 2$

82

Apart from this generally accepted classification, it might be interesting to represent the post-Communist transformation of economy as three different strategies, namely "Gradualism" (implemented in Hungary), "Shock Therapy" (which has its origin in Poland and Czechoslovakia), and the "Third Road" (the cradle of which is considered to be found in the Balkans); the latter consists in so-called "Gradual Gradualism", which means that transition to market is a very long process, the privatisation programme is limited to small enterprises, and private ownership is allowed only in trade, services and tourism (Berend, 1995, pp. 133-7). The "Third Road" might be of special interest only to those who are concerned about the idiosyncrasies of gradualism (specifically, the extreme forms of it). In this connection, it is important to note that very often it is the speed of reforms rather than core values and theoretical beliefs that lies at the heart of disagreements between economists (Birman, 1996, p. 521).

The "Shock Therapy" (which is basically used by the Russian economists), or "Big Bang” (e.g. Kowalik, 1994, p. 116), or "Bitter Pill” (Adams and Brock, 1993, p. XIII) is a strategy which consists in the maximisation of radical transformations in the shortest possible period of time. The key elements of the strategy of "Shock Therapy" include liquidation (or, at least, minimisation) of budget deficit and pursuit of tight monetary policy under the conditions of fixed money supply or fixed exchange rate. The "Shock Therapy" doctrine stems from the orthodox macroeconomic stabilisation scenario (e.g. Kiseliova, 1996, p. 113), which stipulates that budget deficit should be liquidated (or, at least, minimised) and a tight monetary policy, coupled with a fixed money supply or fixed exchange rate, should be established within a limited period of time. At the same time, success depends a good deal on political stability (Jochem, 1999). It is also important to note that the orthodox scenario of "shock therapy" is identical to so-called "Washington Consensus" which, in turn, forms the basis of the IMF approach to transformational developments (Stiglitz, 1998).

If tight budget and monetary policies are pursued under the conditions of regulated prices and incomes, then there is a macroeconomic stabilisation scenario in place, which is referred to as heterodox or non-orthodox scenario (Kiseliova, 1996, p. 113). Such an approach, as a rule, is applied in those countries where stabilisation programmes have not produced any positive results and to win people's support, as a temporary measure (and only as such), along with orthodox ones, the governments resort to regulated prices and incomes (Rostovskij, 1997, pp. 102-3).

The method of "Shock Therapy" was first applied in West Germany after the end of the Second World War. It started its "new life" in post-Communist Poland (Aleksashenko, 1990; Balcerowicz, 1994, 1995, pp. 273-369; Blanchard et al., 1994, pp. 17-22; Johnson and Kowalska, 1994; Narinskiy, 1990; Pankow, 1993; Sachs, 1993; Schaffer, 1992; Wellisz, 1997). Later different variants on the same method were applied with a different level of success in many other post-Communist countries (Alekseev et al., 1995, p. 465), including some former Soviet republics (Stroev et al., 1999, pp. 285-352).

The gradualists, who support the idea of gradual, step-by-step reforms (World Bank, 1996, pp. 11-16), have built their criticism of the "Shock Therapy" method on highlighting inconsistencies and contradictions between different aspects of this strategy that may become evident during accelerated implementation of reforms (Krogel et al., 1992). 
Traditional debates between the advocates of "Shock Therapy" and the gradualists often resembles the "Theater of the Absurd" (Adams and Brock, 1993, p. XV). An illustrative example of this is a quasi-scientific comparison, based on a very superficial resemblance, according to which the "Shock Therapy" supporters are seemingly the followers of Marx (?!), whereas the gradualists are also seemingly the continuators of the German Historical School (Avtonomov, 1997, pp. 6-7).

The main mistake of gradualists, in our opinion, consists of their overlooking some very practical and important conditions that could be elevated to the level of necessary conditions to gradual reforming.

In particular, the success of gradual reforms depends on certain political guarantees, which should, firstly, ensure positive evaluation of reforms by the people and, secondly, enable the government to keep control of the national economy in their hands. As the experience of post-Communist reforms has demonstrated, in many countries (and, first of all, in the USSR at the times of "Perestroika") this essential condition was not (or more precisely could not be) met (World Bank, 1996, pp. 11-16).

Of no less importance is the second condition, which requires strong financial support of reforms and without which the success of post-Communist transformations is inconceivable. If a nation cannot afford such support, it should request international financial institutions and the G-7 nations for assistance. These latter, due to an established practice, ask the IMF for their opinion. The IMF, in turn, backs the "Washington Consensus", which is the same thing as the "Shock Therapy". This means that the gradualist approach, if applied, will require a government to have huge reserves of its own financial resources, all other things being equal.

China, the country that has preserved the Communist regime, in its "softer" form though, represents a classical example of gradual reforms (Boone et al., 1998, pp. 153-81; Cheung, 1998a; Nafziger, 1997, pp. 597-607). It is noteworthy that the retention of a leading role by the Communist Party was a stability factor of market (or quasi-market) reforms not only in China, but also in Vietnam (Dang, 1999; Kolodko, 2000, pp. 73-8). Furthermore, under such circumstances, more or less a long period of time has to pass before the government ventures on reforms (Diykanbayeva, 2001, p. 6).

However, the chances of replicating the Chinese experience in other countries are very little, as there are no guarantees that the above essential conditions precedent to success of gradual implementation of market reforms will be in place. Specifically, inability to meet the first condition precedent to the practical implementation of the gradualist approach, as well as a number of other historical/political factors prevented the governments of the former USSR and the most of post-Soviet countries even from considering the issue of transplanting the Chinese experience into their national contexts (Yevstigneeva and Yevstigneev, 1999, p. 10; Mau, 1999, pp. 6-9). There are some prominent economists in the world though (not to mention ordinary ones), who like to entertain themselves with reflections on utopian models like this. For example, Stiglitz (1999, pp. 1-3, 25), winner of the 2001 Nobel Prize in Economics, the former senior vice president and the chief economist of the World Bank remarks that the Chinese model seemingly could have been adopted by Russia and other former Soviet republics. Unfortunately, this authoritative economist shows complete disregard for the history of formation of the USSR, as an imperial power, as well as all those political developments and armed conflicts that resulted from the collapse of the empire.

\section{Post-Communist economic transition}

83 
IJSE

$32,1 / 2$

\section{4}

Another reason why the Chinese model was essentially infeasible on the Soviet soil was that by the time of Mikhail Gorbachev's coming to power the authority of the Communist Party Leader, due to consistent - even if unconscious - "attempts" of Nikita Khruschev and Leonid Brezhnev, had significantly been weakened and gradually been divided between different levels of the Communist Party's and the Soviet government's bureaucratic/hierarchical machine. In China, however, even though Deng Xiaoping renounced extreme dogmas of Maoism, he never relinquished those powers that had been established in the Chinese system of governance since the epoch of "Cultural Revolution". Furthermore, while the regime of "Perestroika" initiated by Gorbachev was preceded by the period of so-called "inertial immobility", Deng embarked on reforms on the "remains" of "Cultural Revolution" (Aslund, 1995, Ch. 1). In other words, theoretically, from the political standpoint, the best possible (while practically the only possible) chance to implement Chinese reforms in the former USSR was at the hands of the Soviet leadership at the time of Stalin's death.

The "mystery" of success of the Chinese reforms could be explained by: first, high percentage of domestic investments in GDP; second, consistency of government's decisions with respect to gradual implementation of market mechanisms (first of all, in terms of establishing "free economic zones"); third, mass employment of the managers of Chinese descent trained in different developed countries by Chinese companies; and fourth, relatively low percentage (only 18 percent) of employment in large government-owned enterprises (Thurow, 1996, pp. 53-8).

The above explanation of the success of the Chinese reforms sheds more light on those objective preconditions that are necessary for the implementation of gradual reforms and that are missing in many other post-Communist countries. All this allows us to conclude is that the success of the gradualist approach in China depended a lot on peculiarities of national context, which, by itself, by no means can demonstrate any advantages of such an approach (Bogomolov, 1998, p. 50). Furthermore, it is important to note that drawn-out reforms resulted in the loosening of fiscal/budgetary control in China, which in turn did much harm to the national economy (Tanzi, 1994, Ch. 13).

Uzbekistan represents another remarkable example of the gradualist approach to market-oriented reforms (Khikmetov, 2001). Although unlike China the Communist regime did not survive in this country, it was replaced with no less an authoritarian system of governance which, on the one hand, has never renounced quasi-democratic Communist approaches (e.g. only two political parties - both loyal to the president of Uzbekistan - were allowed to take part in the parliamentary elections in 1994; during the recent "successful" referendum a huge majority of people "voted" for the delay of a presidential election) (Apostolou, 1997, p. 101). Among the key achievements of the Uzbek model of gradual reforms are often mentioned the slowest fall of gross domestic product (GDP) rate among all post-Soviet countries (18 percent in 1990-1995), preservation of industrial output almost at the same level (Zhukov, 1997, p. 48), and the intervention of significant foreign investments (Safaev, 1997, p. 100). It must be emphasised, however, that Uzbekistan is very rich in strategic resources, such as gold, oil, cotton and wheat, which is a key factor of the country's economic growth and makes the "triumph" of the Uzbek model of reforms much less impressive (Kasenov, 1998, pp. 37-40; Rumer, 2000, pp. 36-47; Trushin, 1998a, b; Zhukov, 2000, pp. 160-9). In this context, noteworthy is the assumption that as a rule, any deviation from common 
sense in any country's economic policy must be explained by national peculiarities the content of which very often might not be explained at all (Segvari, 1999, pp. 49-50).

As a general rule, no economy that is undergoing the process of post-Communist transformation can avoid a drastic decline in production as a whole and in industrial output, in particular; the fall of labour efficiency, investments and real incomes (Nove, 1993, p. 22; 1995, pp. 227-30). It is also important to note that at the initial stage of post-Communist transformation there is a high correlation between the reduction in production size and the fall of production capacity (Kolodko, 2000, pp. 252-6). To be more specific, the decrease in output most often takes place in those companies that were established before the start of post-Communist transformations (Konings and Walsh, 1998). Accordingly, the tendency to decline originates in the Communist regime itself (Aslund, 2001a). It is also believed that successful post-Communist reforms may result in a shift from the fall of production to its growth (Winckler, 1992), which means that the production curve is a U-shaped one (Blanchard, 1997, pp. 1-20). In this regard, it must be emphasised that there is no agreement between the economists on the reasons for such a shift to economic growth (Tanzi, 1997, pp. 315-16). In conclusion, we would like to agree with Galbraith who remarks that economic growth is always accompanied by destructive tendencies resulting from the growth itself, for which reason recession or depression becomes inevitable (Inozemtsev, 1998, p. 14).

The experience of fast economic reforms implemented in different countries demonstrates that the deterioration of living conditions of a vast majority of people is a universal phenomenon, which is caused by the fall of production, increases in prices and decreases in real incomes (Standing, 1997, pp. 230-4). This phenomenon is often referred to as "Transformational Fall" (Kornai, 1993), "Transformational Crisis" (Nikipelov, 1996, pp. 189-90; Olsevich, 1997a, pp. 255-77; Zukowski, 1996), "post-Communist Great Depression” (Milanovic, 1998, pp. 23-30), "Trap of Reforms” (Klaus, 1997, p. 184), the cause of which lies not in the essence of "Shock Therapy", but rather in the negation of the latter (Mau, 1999, p. 11), delays in implementing reforms (Asslund, 2001b), and of course, in the collapse of the old system (Sachs, 1994, Ch. 4), as those countries that opted for the "shocking" reforms were first to enter the phase of economic growth (de Melo et al., 1997; Gaidar, 1997, p. 11).

It is noteworthy that the said "Transformational Crisis" often casts doubts on the reformers' ability to maintain political stability, for which reason initiators of the "shocking" reforms, as a rule, have to resign from their positions (classical examples include Balcerowicz in Poland and Gaidar in Russia in the early 1990s) (Crawford, 1995, p. 11).

The practice has shown that the "Shock Therapy" produces the best results in such countries where the status of the economy before the reforms (or before the "shock") was so bad that the people were ready to tolerate whatever is necessary to overcome the existing situation (Geiger, 1992, Ch. 13). In that case, negative effects of the "shock" are disregarded, whereas positive ones are so apparent that the initiators of the "Shock Therapy" can feel secure from any political threat.

Thus, the success of the "Shock Therapy" rests on the paradox: "The Worse, the Better". If there is a big question mark over the country's future and its ability to survive, there must be no doubt whether the "Shock Therapy" method is really needed, as under such circumstances the country has no choice and positive results are almost

\section{Post-Communist economic transition}

85 
IJSE

$32,1 / 2$

86 guaranteed. Such a situation might be classified as "Minimal Shock with Maximum Therapy"or "Soft Big Bang" (Papava, 2002b, pp. 54-5).

There is a universally accepted assumption that the developed nations ought to support the post-Communist countries in order to provide them with some "relief" from pains that these latter suffer from in the course of post-Communist transformation. In the meantime, such a relief may become a key obstacle in the way of reforms as it may reduce an ability to appreciate the need and inevitability of reforms and may tempt governments into postponing the implementation of radical reforms (Becker and Becker, 1997, pp. 261-2). Jeffrey Sachs believes that to avoid such negative effects, financial aid to the reformist governments should be tightly associated with the fulfilment of certain strict conditions and the biggest portion of such aid should be used for the alleviation of hard social conditions of the population. However attractive this suggestion may be, its rightness is still questionable (Hinshaw, 1996, pp. 128-30).

A post-Communist country's choice of the economic policy model depends on whether decision-makers, as well as their supporters and opponents have (e.g. Abalkin, 1996) or have not (e.g. Illarionov, 1996) taken into account the above-described necessary conditions of gradual reforming.

In this connection, it must also be noted that the opponents' criticism of "Shock Therapy" is based, on the one hand, on their assumption that the monetarist scheme this approach rests on is useless in terms of dealing with the problems of post-Communist transformation (e.g. Abalkin, 1996; Fedorenko, 2001, pp. 412-13) and, on the other hand, on their claim that it has nothing to do with true monetarism and that instead it proposes "false monetarism" (Olsevich, 1997b). More precisely, it is not pure monetarism that we are dealing with in this particular case, but rather its combination with the neoclassical theory, where the latter makes a conceptual basis and the former provides guidelines for actions (Menshikov, 1996, pp. 106-7). They also claim that the "Shock Therapy" method is good for "treating" the market, but is no good for creating it (Petrakov, 1998, pp. 194-5; Menshikov, 1996, pp. 113-15).

To the extent that the monetarist approach to post-Communist reforms is broadly applied by the IMF (Allen, 1992) and the World Bank in their financial/economic programmes, the opponents of "Shock Therapy" mechanically criticise those programmes too (e.g. Abalkin, 2001, pp. 46-50). It is interesting, however, that a history (in modern sense of this word) of such criticism dates from to the "pre-post-Communist" or the "pre-shock" period (Nafziger, 1997, pp. 566-74).

We all make mistakes and so does the IMF (e.g. Papava 2003; Stiglitz, 2002). Its recommendations sometimes are good and sometimes are bad (Hinshaw, 1996, p. 134), but its goals are always acceptable to almost all. For example, many people among the Russian scientific and political circles generally agree to the assumption that the IMF goals are not in conflict with Russia's interests in the country's economic security, whereas from the standpoint of some peculiarities typical of the national context the IMF's recommendations do make a threat to the country's economic security (Veduta, 1998, pp. 328, 362).

In this connection, especially interesting is the disagreement that occurred between the World Bank and the IMF at the end of the twentieth century. Specifically, the former refused to accept the conceptual approaches of the latter, called for the IMF to revise its traditional policies and proposed an essentially new approach which 
consisted in the elimination of the elements of "Shock Therapy" in the institutional reforms policy (Stiglitz, 1998, 1999; World Bank, 1999).

\section{On the newest trends in economic theory and post-Communist transformation of economy}

The correlation between economic and political liberties and their mutual impact on each other (Friedman, 1982, pp. 7-21) allows us rightly to understand all those mechanisms by which political factors influence the process of post-Communist transition to market economy (Braguinsky, 1998; Cheung, 1998b; Intriligator, 1998). Furthermore, it allows us to conclude that a theory of "Public Choice" is the best doctrine that might be applicable to this process (Lavigne, 1995, pp. 249-50). Although the said theory was developed in relation to the developed economies (Buchanan and Tullock, 1962), later it was successfully used for the purposes of developing countries as well. In addition, in the economic/research literature it is often referred to as a "New Political Economy" (Paulson, 1994, p. 97) and can be used more or less successfully to study post-Communist transformations too (Paulson, 1994, Ch. 18). In particular, this theory provides very good results in terms of the analysis of the process accelerating or braking mechanisms (e.g. Murrell, 1991).

As far as the need of developing constructive conceptual basis for economic reforms is concerned, particularly attractive seems to be the so-called institutional approach (e.g. Intriligator, 1997; Intriligator et al., 1999; North, 1997; Papava and Khaduri, 1997) one of the elements of which - the evolutionary theory (Hamilton, 1991; Nelson and Winter, 1982) - has effectively been used for the study of the problems of post-Communist transformations (Murrell, 1991). The concept of "Routine" is a key "tool" of this theory which is defined as established rules and methods by which the company's business behaviour is reproduced. The followers of the evolutionary theory who deduce their key assumptions from the analysis of "Routine" that existed in the organisations before the start-up of the post-Communist reforms, consider that new market-style organisations must be encouraged, but in the process of gradual transformation old organisations should coexist with the new ones.

Thus, they distinguish the following two ways of transition to market economy: the "top-down" and the "bottom-up" ones. The first path consists of the mandatory privatisation of government-owned enterprises, whereas the other requires that the structure of the economy be modified by establishing new companies and encouraging the development of already existing private firms (Brezinski and Frirsh, 1996, p. 297); these measures, under the conditions of appropriate macroeconomic policy - namely, as a temporary measure, imposing "light" tax burden on businesses - must ensure an evolutionary transition from the Communist-style economy to market. It must be emphasised that recently the president of the World Bank has developed a new "Comprehensive Development Framework" (Wolfenson, 1999), according to which a priority should be given to the bottom-up option (Stiglitz, 1999, p. 25). It is desirable that this approach be taken as a basis of national strategic development programme of each post-Communist state (e.g. Koichuev, 2001, pp. 163-94).

Another doctrine which is in full harmony with the evolutionary theory is (Gutnik, 1996, 2002) that of "Economic Order" (Eucken, 1949, 1952) which, depending on the context and the given historical epoch, provides the "key" to understanding the structure of economy in transition (Avtonomov, 1999).

\section{Post-Communist economic transition}


IJSE

$32,1 / 2$

It is important to note that very often the evolutionary approach to post-Communist development is equated with gradualism (Lavigne, 1995, p. 250). In doing so, they fail to notice the fact that neither the "Shock Therapy" method can be "confined" to one single action in the course of post-Communist transformation. This can be explained in a simple way if we take into account the fact that transition to market economy requires implementation of a set of the following six steps (Lipton and Sachs, 1990):

(1) macroeconomic stabilisation;

(2) liberalisation of prices;

(3) liberalisation of foreign trade and ensuring convertibility of national currency in accordance with current transactions;

(4) company reform, first of all, through privatisation;

(5) establishing a social security system; and

(6) developing an institutional and legal infrastructure of market economy (and a market-based financial system in it).

This set of six steps could be presented in a different arrangement; for example, macroeconomic stabilisation may be split into monetary and fiscal elements, whereas the company reform and the institutional structure development may be combined to form one group (Wolf, 1994, pp. 170-6).

Out of the above six steps, only the first three can be taken in a quick manner (quickness, on the one hand, is a key condition of "Shock Therapy" and, on the other hand, constitutes an essence of "Washington Consensus" (Stiglitz, 1998)), whereas the implementation of the rest will need a much longer period of time in any setting, as establishing institutional and legal infrastructure, because of particularly complicated nature of the task (Boettke, 1998), is likely to take many decades (World Bank, 1996, pp. 11-12). It is exactly owing this assertion that once very tensed debates between the "Shock Therapy" advocates and the gradualists have become softer (Papava, 2000, p. 4).

It must be emphasised that although the "Shock Therapy" method is really ineffective for developing market institutions, the acceptance - at least, theoretically of the assumption that post-Communist reforms should have started with institutional changes only (Kolodko, 1999; Stiglitz, 1999) and that liberalisation and stabilisation programmes should have been embarked on only after the accomplishing of this task would amount to the refusal to establish all those market signals that are necessary to foster the development of private sector in a long-term perspective, as well as the "conservation" of a major part of Communist-style mechanisms of economic regulation. In other words, one who accepts the idea that post-Communist transformations must start with merely institutional reforms is about to cause severe delays in the process of establishing market economy and democratic system of economic regulation.

To the extent that post-Communist transformation is, by nature, a long process, there emerge natural questions:

- Which way should the reform go after the end of "Shock Therapy"?

- What steps should be taken to follow up and build on the achievements of "Shock Therapy"? 
One possible answer to these questions rests on a "Social Promotion" method of economic reforms which requires to create certain conditions that by encouraging the formation of a strong class of businesspeople will speed up the process of social stratification; on the other hand, to ensure support of reforms on the part of low-income groups and improve their hard living conditions, a consistent and a beneficiary-oriented social assistance policy should be developed and implemented (Papava, 1996a, pp. 260-7; 1996b, 1999, pp. 281-91). A combination of well-known mechanisms of promoting supply and demand, namely the so-called Laffer/Keynesian Synthesis, is proposed as a theoretical base of the "Social Promotion" method (Papava, 1996a, pp. 263-4, 266-7; 1999, pp. 287-91).

In conclusion, it must be noted that to date there is no special economic theory of post-Communist transformation. It is just in the process of developing (Papava, 2000). Nevertheless, some well-known economic theories and combinations of certain elements of the latter could be used more or less successfully to produce a complete analysis of the collapse of Communist economic system (e.g. Rosser and Rosser, 1997) and to develop effective economic policy mechanisms applicable to the period of post-Communist transformations (e.g. Sušjan and Lah, 1997).

\section{References}

Abalkin, L.I. (1996), "Economic realities and abstract schemes (concerning a conceptual basis of the Monetarist Financial Stabilization Program)”, Voprosy ekonomiki, No. 12, pp. 4-19 (in Russian).

Abalkin, L. (Ed.) (1997), A Course on Transitional Economy, Finstatinform, Moscow (in Russian).

Abalkin, L.I. (2001), Challenges of a New Century, IE RAN, Moscow (in Russian).

Adams, W. and Brock, J.W. (1993), Adam Smith Goes to Moscow. A Dialogue on Radical Reform, Princeton University Press, Princeton, NJ.

Aleksashenko, S. (1990), "Economic reform: a Polish path", Mirovaja ekonomika $i$ mezhdunarodnye otnoshenija, Vol. 7 No. 17, p. 29 (in Russian).

Alekseev, A.M. et al. (1995), Modern Civilized Market. International Experience and Its Application in CIS , EA, Moscow (in Russian).

Allen, M. (1992), "IMF - supported adjustment programs in Central and Eastern Europe", in Winckler, G. (Mod.), Central and Eastern Europe Roads to Growth, Papers Presented at a Seminar Held in Baden, Austria, April 15-18, 1991, IMF, Washington, DC, pp. 23-50.

Andor, L. and Summers, M. (1998), Market Failure. Eastern Europe's “Economic Miracle”, Pluto Press, London.

Antachak, R., Guzhinski, M. and Kozarzhevski, P. (2001), Economy of Belarus from Market to Planning Vol. 2, CASE, Warsaw, (in Russian).

Apostolou, A. (1997), "Is the Uzbek model working? No: political repression thwarts economic growth”, Transitions, Vol. 4 No. 2, pp. 99-101.

Åslund, A. (1995), How Russia Became a Market Economy, Brookings Institute, Washington, DC.

Åslund, A. (2001a), "The myth of output collapse after Communism”, Voprosy ekonomiki, Vol. 7 No. 115, p. 138 (in Russian).

Åslund, A. (2001b), "Building capitalism: lessons of the post-Communist experience", Policy Brief, No. 10, Carnegie Endowment for International Peace, Washington, DC, December.

\section{Post-Communist economic transition}


IJSE

$32,1 / 2$

Aukutsionek, C. (1996), "Theory of transitional economy and its place in a system of economic science”, Mirovaja ekonomika i mezhdunarodnye otnoshenija, Vol. 10 No. 11, p. 23 (in Russian).

Avtonomov, V.S. (1996), "Political economy of transitional period", Mirovaya ekonomika $i$ mezhdunarodnye otnoshenija, No. 9, pp. 5-15 (in Russian).

Avtonomov, V.S. (1997), “Market behavior': rational and ethical aspects”, Mirovaya ekonomika $i$ mezhdunarodnye otnoshenija, No. 12, pp. 6-13 (in Russian).

Avtonomov, V.S. (Ed.) (1999), Social Market Economy. Theory and Ethics of Economic Order in Russia and Germany, Ekonomicheskaya Shkola, St Petersburg (in Russian).

Balcerowicz, L. (1994), "Poland, 1989-92”, in Williamson, J. (Ed.), Political Economy of Economic Reform, Institute for International Economics, Washington, DC.

Balcerowicz, L. (1995), Socialism, Capitalism, Transformation, CEU, Budapest.

Basilia, T., Silagadze, A. and Chikvaidze, T. (2001), Post-Socialist Transformation: Georgian Economy at the Turn of the 21st Century, CASE, Tbilisi (in Georgian).

Becker, G.S. and Becker, G.N. (1997), The Economics of Life. From Baseball to Affirmative Action to Immigration, How Real World Issues Affect Our Everyday Life, McGraw-Hill, New York, NY.

Bell, D. (1976), The Coming of Post-industrial Society, Basic Books, New York, NY.

Belokrylova, O.C. (2002), Theory of Transitional Economy, Phoenix, Rostovna-Donu (in Russian).

Berend, I.T. (1994), "End of century global transition to a market economy: laissez-faire on the peripheries?", in Berend, I.T. (Ed.), Transition to a Market Economy at the End of the 20th Century, 11th International Economic History Congress, Session A-3, Milan, September 12-17, Sutdeseuropa-Ges, München, pp. 9-54.

Berend, I.T. (1995), "Alternatives of transformation: choices and determinants - East-Central Europe in the 1990s", in Crawford, B. (Ed.), Markets, States, and Democracy: the Political Economy of Post-Communist Transformation, Westview Press, Boulder, CO, pp. 130-49.

Berezin, I. (1999), The Short History of Economic Development, Russian Business Literature, Moscow, (in Russian).

Bertenev, S.A. (1996), Economic Theories and Schools (History and Modern Time), BEK, Moscow (in Russian).

Birman, I. (1996), I'm an Economist (about Myself, the Beloved One) , EKOR, Novosibirsk (in Russian).

Blanchard, O. (1997), The Economics of Post-Communist Transformation, Clarendon Press, Oxford.

Blanchard, O., Dornbush, R., Krugman, P., Layard, R. and Summers, L. (1994), Reform in Eastern Europe, The MIT Press, Cambridge, MA.

Boettke, P.J. (1998), "Promises made and promises broken in the Russian transition", Constitutional Political Economy, Vol. 9 No. 2, pp. 133-42.

Bogomolov, O.T. (1998), Reforms in a Mirror of International Comparisons, Ekonomika, Moscow (in Russian).

Boone, P., Gomulka, S. and Layard, R. (Eds) (1998), Emerging from Communism. Lessons from Russia, China, and Europe, The MIT Press, Cambridge, MA.

Boźyk, P. (1999), "Gradualism versus shock therapy", in Hare, P.G. (Ed.), Systemic Change in Post-Communist Economies, Selected Papers from the 5th World Congress of Central and East European Studies, Warsaw, 1995, Macmillan Press, London, pp. 25-38. 
Braguinsky, S. (1998), "Democracy and economic reform: theory and some evidence from Russian case”, Contemporary Economic Policy, Vol. XVI No. 2, pp. 227-40.

Brezinski, H. and Frirsh, M. (1996), "Bottom up transformation: prerequisites, scope and impediments”, International Journal of Social Economics, Vol. 23 No. 10-11, pp. 297-310.
Post-Communist economic transition

Brown, M.B. (1995), Models in Political Economy. A Guide to the Arguments, Penguin Books, London.

Buchanan, J.M. (1992), "Economics in the post-Socialist century", in Hey, J.D. (Ed.), The Future of Economics, Blackwell, Oxford, pp. 15-21.

Buchanan, J.M. and Tullock, G. (1962), The Calculus of Consent: Logical Foundations of Constitutional Democracy, University of Michigan Press, Ann Arbor, MI.

Bukharin, N.I. (1990), "Economy of transitional period", Collected Works, Ekonomika, Moscow, pp. 5-274 (in Russian).

Buzgalin, A.V. (1994), Economy in Transition: A Course of Lectures in Political Economy, Taurus, Moscow (in Russian).

Calkins, P. and Vezina, M. (1996), "Transitional paradigms to a new world economic order", International Journal of Social Economics, Vol. 23 No. 10-11, pp. 311-28.

Campbell, R.W. (1991), The Socialist Economies in Transition: A Primer on Semi-reformed Systems, Indiana University Press, Bloomington, IN.

Cheung, S.N.S. (1998a), "Den Xiaoping's great transformation”, Contemporary Economic Policy, Vol. XVI No. 2, pp. 125-35.

Cheung, S.N.S. (1998b), "The curse of democracy as an instrument of reform in collapsed Communist economies", Contemporary Economic Policy, Vol. XVI No. 2, pp. 247-9.

Claessens, S. and Glaessner, T. (1997), Are Financial Sector Weaknesses Undermining the East Asian Miracle?, The World Bank, Washington, DC.

Crawford, B. (1995), "Post-Communist political economy: a framework for the analysis of reform", in Crawford, B. (Ed.), Markets, States, and Democracy: The Political Economy of Post-Communist Transformation, Westview Press, Boulder, CO.

Dang, T.K.L. (1999), Vietnam: Transition to Market, IE RAN, Moscow (in Russian).

Davidson, J.D. and Rees-Mogg, W. (1998), The Sovereign Individual. The Coming Economic Revolution. How to Survive and Prosper in it, Pan Books, London.

de Melo, M., Denizer, C. and Gelb, A. (1997), "From plan to market: patterns of transition", in Blejer, M.I. and Skreb, M. (Eds), Macroeconomic Stabilization in Transition Economies, Cambridge University Press, Cambridge, pp. 17-72.

Derlien, H.-U. (1999), "The triple revolution: administrative transformation in the former GDR", in Nunberg, B., (with contributions by Barbone, L. and Derlien, H.-U.), The State after Communism: Administrative Transition in Central and Eastern Europe, The World Bank, Washington, DC, pp. 195-235.

Diykanbayeva, G. (2001), "Some aspects of the reform of financial sector in Kyrgyzstan and the experience of the countries of South-East Asia", Experience in Developing Financial and Fiscal Systems and Attracting Direct Investments in East Asia: Lessons and Recommendations, Almaty, pp. 3-11 (in Russian).

Drucker, P.F. (1993), Post-Capitalist Society, HarperBusiness, New York, NY.

Esping-Andersen, G. (Ed.) (1997), Welfare States in Transition. National Adaptations in Global Economies, Sage Publications, London.

Eucken, W. (1949), Die Grundlagen der Nationalökonomie, Springer-Verlag, Berlin.

Eucken, W. (1952), Grundsätze der Wirtschaftspolitik, J.C.B.Mohr (Paul Siebeck), Tübingen. 
IJSE

$32,1 / 2$

92
Fedorenko, N.P. (2001), Russia: Lessons of the Past and Outlines of the Future, ZAO "Ekonomika" Publishing, Moscow (in Russian).

Feldstein, M. (Ed.) (1980), The American Economy in Transition, The University Press, Chicago, IL.

Friedman, M. (1982), Capitalism and Freedom, The University of Chicago Press, Chicago, IL.

Gaidar, E. (1997), Anomaly of Economic Growth, Eurasia, Moscow, (in Russian).

Galbraith, J.K. (1992), "Economics in the century ahead", in Hey, J.D. (Ed.), The Future of Economics, Blackwell, Oxford, pp. 41-6.

Galbraith, J.K. (1996), The Good Society. The Humane Agenda, Houghton Mifflin, Boston, MA.

Galbraith, J.K. (1998), The Affluent Society, 40th anniversary ed., Mariner Books, Boston, MA.

Geiger, L.T. (1992), Macroeconomic Analysis and Transitional Economy, Eastern College, St Davids.

Goldstone, J. (2001), "Theories of revolution, the revolutions of 1989-1991 and the trajectory of the 'new' Russia”, Voprosy ekonomiki, No. 1, pp. 117-24 (in Russian).

Gutnik, V. (1996), "Renaissance of the theory of economic transition", Mirovaya ekonomika $i$ mezhdunarodnye otnoshenija, No. 10, pp. 5-9 (in Russian).

Gutnik, V. (2002), Policy of Economic Transition in Germany, Ekonomika, Moscow, (in Russian).

Hamilton, D. (1991), Evolutionary Economics. A Study of Change in Economic Thought, Transaction Publishers, New Brunswick, NJ.

Heilbroner, R. and Milberg, W. (1996), The Crisis of Vision in Modern Economic Thought, Cambridge University Press, Cambridge.

Hinshaw, R. (Ed.) (1996), The World Economy in Transition. What Leading Economists Think, Edward Elgar, Cheltenham.

Hoen, H.W. (1999), “'Shock versus gradualism': the inappropriateness of the labels applied to the strategies in Central Europe", in Hare, P.G. (Ed.), Systemic Change in Post-Communist Economies, Selected Papers from the 5th World Congress of Central and East European Studies, Warsaw, 1995, Macmillan Press, London, pp. 39-61.

Ignatenko, A.A. (1988), Caliphs without Caliphate. Islamic Non-governmental Religious/Political Organizations in the Middle East: History, Ideology, Activities, Nauka, Moscow (in Russian).

Illarionov, A. (1996), "Models of economic development in Russia", Voprosy ekonomiki, No. 7, pp. 4-17 (in Russian).

Inozemtsev, V.L. (1995), Contribution to the Theory of Post-economic Formation of Society, Taurus, Moscow (in Russian).

Inozemtsev, V.L. (1998), "Rethinking of the future. Most prominent American economists and sociologists about the perspectives and contradictions of modern development", Mirovaya ekonomika i mezhdunarodnye otnoshenija, No. 11, pp. 5-26.

Intriligator, M. (1997), "Reforming the Russian economy: the role of institutes", Ekonomika $i$ matematicheskie metody, Vol. 33 No. 3, pp. 16-29 (in Russian).

Intriligator, M.D. (1998), "Democracy in reforming collapsed Communist economies: blessing or curse?", Contemporary Economic Policy, Vol. XVI No. 2, pp. 241-6.

Intriligator, M.D., Braguinsky, S., Bowen, J.R. II, Tullock, G. and Root, H.L. (1999), "Role of market institutions in Pacific Rim development and transition", Contemporary Economic Policy, Vol. XVII No. 1, pp. 109-37. 
Jochem, A. (1999), "Monetary stabilization in countries in transition", International Advances in Economic Research, Vol. 5 No. 1, pp. 23-35.

Johnson, S. and Kowalska, M. (1994), "Poland: the political economy of shock therapy", in Haggard, S. and Webb, S.B. (Eds), Voting for Reform. Democracy, Political Liberalization, and Economic Adjustment, Oxford University Press, Oxford, pp. 185-241.

Kanth, R.K. (1997), Against Economics. Rethinking Political Economy, Ashgate, Aldershot.

Kasenov, U. (1998), "Post-Soviet modernization in Central Asia: realities and prospects", in Rumer, B. and Zhukov, S. (Eds), Central Asia: The Challenges of Independence, M.E. Sharpe, Armonk, NY, pp. 57-69.

Khikmetov, A.K. (Ed.) (2001), Uzbekistan: Ten Years in the Way to Market Economy, Tashkent, (in Russian).

Kiseliova, E.A. (1996), "Macroeconomic stabilization: the orthodox and heterodox scenarios", in Kiseliova, E.A. and Chepurin, M.N. (Eds), Elements of the Theory of Transitional Economy (in Russian), KOT, Kirov, pp. 111-32.

Klaus, V. (1997), "Promoting financial stability in the transition economies of Central and Eastern Europe”, Maintaining Financial Stability in a Global Economy, a Symposium Sponsored by The Federal Reserve of Kansas City, Jackson Hole, WY, August 28-30,, pp. 183-92.

Koichuev, T. (2001), The Economy of Kyrgyz Republic on the Way of Reforms, Reform, Bishkek.

Kolodko, G.V. (1999), "Lessons of ten years of post-Communist transformation", Voprosy ekonomiki, No. 9, pp. 19-32.

Kolodko, G.V. (2000), From Shock to Therapy. Political Economy of Post-Socialist Transformations, ZAO Zhurnal Ekspert, Moscow (in Russian).

Konings, J. and Walsh, P.P. (1998), "Disorganization in the transition process: firm level evidence from Ukraine”, LICOS Discussion Paper 71/1998, Center for Transition Economies, Katholieke Universiteit Leuven, Leuven.

Kornai, J. (1992), The Socialist System. The Political Economy of Communism, Princeton University Press, Princeton, NJ.

Kornai, J. (1993), "Transformational recession: a general phenomenon examined through the example of Hungary's development", Discussion Paper, No. 1, Institute for Advanced Study, Collegium Budapest, Budapest, June.

Kowalik, T. (1994), "The 'big bang' as a political and historical phenomenon: a case study on Poland", in Berend, I.T. (Ed.), Transition to a Market Economy at the End of the 20th Century, 11th International Economic History Congress, Session A-3, Milan, September 12-17, Sutdeseuropa-Ges, München, pp. 115-23.

Krogel, J., Mazner, E. and Grabcher, G. (1992), The Market Shock, AGENDA Group, Vienna (in Russian).

Kuzin, D.V. (Ed.) (1994), "Economic Miracles": Lessons for Russia, OLMA-PRESS, Moscow (in Russian).

Kuznetsov, V. (1994), "Towards the theory of transitional economy", Mirovaya ekonomika $i$ mezhdunarodnye otnoshenija, No. 12, pp. 1-14 (in Russian).

Lavigne, M. (1995), The Economics of Transition, St Martin's Press, New York, NY.

Lipton, D. and Sachs, J. (1990), "Creating a market economy in Eastern Europe: the case of Poland”, Brookings Papers on Economic Activity, No. 1, pp. 75-133.

Mau, V. (1999), "Russian economic reforms from the viewpoint of international critics", Voprosy ekonomiki, No. 11, pp. 4-23 (in Russian).

\section{Post-Communist economic transition}


IJSE

$32,1 / 2$

94
Menshikov, S.M. (1996), "Russian economy: practical and theoretical aspects of transition to market", Mirovaya ekonomika i mezhdunarodnye otnoshenia, Moscow (in Russian).

Mikulskiy, K.I. (1999), "Concerning the modern phase and mechanisms of overcoming system crisis of post-Socialist society", Obschestvo i ekonomika, No. 10-11, pp. 8-13 (in Russian).

Milanovic, B. (1998), Income, Inequality and Poverty during the Transition from Planned to Market Economy, The World Bank, Washington, DC.

Murrell, P. (1991), "Public choice and the transformation of socialism", Journal of Comparative Economics, Vol. 15 No. 2, pp. 203-10.

Nafziger, E.W. (1997), The Economics of Developing Countries, Prentice-Hall, Upper Saddle River, NJ.

Narinskiy, R. (1990), "Economic program of the Mazovetsky Government", Voprosy ekonomiki, No. 4, pp. 110-11, (in Russian).

Nelson, R.R. and Winter, S.G. (1982), An Evolutionary Theory of Economic Change, The Belknap Press of Harvard University Press, Cambridge, MA.

Nikipelov, A.D. (1996), Essays on Post-Communist Economies, CISN, Moscow (in Russian).

Nikolaeva, I.P. (Ed.) (2001), Theory of Transitional Economy, UNITY-DANA, Moscow, (in Russian).

Nolan, P. (1995), "Politics, planning, and the transition from Stalinism: the case of China", in Chang, H.J. and Rowthorn, R. (Eds), The Role of the State in Economic Change, Clarendon Press, Oxford.

North, D. (1997), "Institutional changes: limits of analysis", Voprosy ekonomiki, No. 3, pp. 6-17 (in Russian).

Nove, A. (1993), "Economics of the transitional period - a critical review", Revue Européenne des Sciences Sociales, Vol. XXXI No. 96, pp. 133-41.

Nove, A. (1995), "Economics of transition: some gaps and illusions", in Crawford, B. (Ed.), Markets, States, and Democracy: The Political Economy of Post-Communist Transformation, Westview Press, Boulder, CO, pp. 227-45.

Nunberg, B. (1999), The State after Communism: Administrative Transitions in Central and Eastern Europe, The World Bank, Washington, DC.

O'Brien, J.C. (1989), “The Communist credo: man is the measure of all things", Allied Social Sciences Association, Annual Conference, Atlanta, GA, December 28-30, Vol. 1989, California State University, Fresno, CA.

Olson, M. (1995), "Devolution of power and society in a transitional period. Remedies to corruption, economic decline and deceleration of economic growth", Ekonomika $i$ matematicheskie metody, Vol. 31 No. 4, pp. 53-81 (in Russian).

Olsevich, Y. (1997a), Towards the Theory of Economic Transformations, IE RAN, Moscow (in Russian).

Olsevich, Y. (1997b), "Monetarism and Russia: the problem of compatibility”, Voprosy ekonomiki, No. 8, pp. 24-37 (in Russian).

Pankow, W. (1993), Work Institutions in Transformation. The Case of Poland 1990-1992, Friedrich Ebert Stiftung, Warsaw.

Papava, V. (1995), "Marxist points of view on the Soviet Communist economic system and the manifestation of egalitarianism in post-Communist economic reform", International Journal of Social Economics, Vol. 22 No. 6, pp. 29-37.

Papava, V. (1996a), “The Georgian economy: from 'shock therapy' to 'social promotion”, Communist Economies \& Economic Transformation, Vol. 8 No. 8, pp. 251-67. 
Papava, V. (1996b), “Social promotion’ of economic reform in Georgia”, Economic Systems, Vol. 20 No. 4, pp. 305-14.

Papava, V. (1999), "The Georgian economy: main directions and initial results of reforms", in Hare, P.G. (Ed.), Systemic Change in Post-Communist Economies, Selected Papers from the 5th World Congress of Central and East European Studies, Warsaw, 1995, Macmillan Press, London.

Papava, V. (2000), "On the theory of post-Communist transformation of economy", Obschestvo $i$ ekonomika, No. 7, pp. 61-77 (in Russian).

Papava, V. (2002a), Leszek Balcerowicz and Georgia, GFSIS, Tbilisi.

Papava, V. (2002b), Political Economy of the Post-Communist Capitalism and its Application for Georgian Economy, PDP, Tbilisi (in Georgian).

Papava, V. (2003), Splendours and Miseries of the IMF in Post-Communist Georgia, We-publish.com, Laredo, TX.

Papava, V. and Khaduri, N. (1997), "On the shadow political economy of the post-Communist transformation. An institutional analysis", Problems of Economic Transition, Vol. 40 No. 6, pp. 15-34.

Paulson, B.W. (1994), Economic Development: Private and Public Choice, West Publishing, St Paul, MN.

Petrakov, N.Y. (1998), The Russian Roulette: An Economic Experiment Costing 150 Million Lives, Vol. 150, Ekonomika, Moscow (in Russian).

Petukhov, S. (1999), “The Georgian economic miracle is already on the way!”, Ogoniok, No. 30, pp. 28-9 (in Russian).

Rakitskaya, G. (1996), "Social/economic strategies in modern Russia”, Voprosy ekonomiki, No. 8, pp. $86-98$ (in Russian).

Rosser, J.R. and Rosser, M.V. (1997), "Schumpeterian evolutionary dynamics and the collapse of Soviet-bloc socialism”, Review of Political Economy, Vol. 9 No. 2, pp. 211-23.

Rostovskij, I. (1997), Macroeconomic Instability in Post-Communist Countries, Ekonomika, Moscow (in Russian).

Rumer, B. (2000), "Economic crisis and growing intraregional tensions", in Rumer, B. (Ed.), Central Asia and the New Global Economy, M.E. Sharpe, Armonk, NY, pp. 3-56.

Sachs, J. (1993), Poland's Jump to the Market Economy, The MIT Press, Cambridge, MA.

Sachs, J. (1994), Market Reforms and Russia, BBC MPM, London.

Safaev, S. (1997), "Is the Uzbek model working? Yes: a triumph of gradualism”, Transitions, Vol. 4 No. 2, p. 98, 100.

Schaffer, M. (1992), "The economy of Poland”, Discussion Paper, No. 67, Center for Economic Performance, LSE, London, March.

Segvari, I. (1999), "Seven different assumptions on Russian reforms: are they right?", Voprosy ekonomiki, No. 9, pp. 45-56 (in Russian).

Shurgalina, I.N. (1997), Reforming the Russian Economy. An Experiment of Analysis in Light of the Catastrophe Theory, ROSSPEN, Moscow (in Russian).

Simonia, N. (1999), "Methodological problems of the analysis of social/economic development models", Obschestvo i ekonomika, No. 10-11, pp. 14-18 (in Russian).

Standing, G. (1997), "Social protection in Central and Eastern Europe: a tale of slipping anchors and torn safety nets", in Esping-Andersen, G. (Ed.), Welfare States in Transition. National Adaptations in Global Economies, Sage Publications, London. 
IJSE

$32,1 / 2$

96
Stiglitz, J.E. (1992), "Another century of economic science", in Hey, J.D. (Ed.), The Future of Economics, Blackwell, Oxford, pp. 134-41.

Stiglitz, J.E. (1996), Whither Socialism?, The MIT Press, Cambridge, MA.

Stiglitz, J. (1998), "More instruments and broader goals: moving toward the post-Washington consensus", WIDER Annual Lectures, No. 2, UNU/WIDER, Helsinki.

Stiglitz, J.E. (1999), "Whither reform? ten years of the transition”, Annual Bank Conference on Development Economics, April 28-30, 1999 The World Bank, Washington, DC.

Stiglitz, J.E. (2002), Globalization and Its Discontents, W.W. Norton \& Company, New York, NY.

Stroev, E.S., Bliakhman, L.S. and Krotov, M.I. (1999), Russia and Eurasia at the Crossroads. Experience and Problems of Economic Reforms in the Commonwealth of Independent States, Springer, Berlin.

Sušjan, A. and Lah, M. (1997), "Inflation in the transition economies: the post-Keynesian view", Review of Political Economy, Vol. 9 No. 4, pp. 381-93.

Tanzi, V. (Ed.) (1994), Transition to Market: Studies in Fiscal Reform, IMF, Washington, DC.

Tanzi, V. (1997), "Economic transformation and the policies for long-term growth", in Blejer, M.I. and Škreb, M. (Eds), Macroeconomic Stabilization in Transition Economies, Cambridge University Press, Cambridge, pp. 313-26.

Thurow, L.C. (1996), The Future of Capitalism. How Today's Economic Forces Shape Tomorrow's World, Penguin Books, New York, NY.

Trushin, E. (1998a), "Uzbekistan: foreign economic activity”, in Rumer, B. and Zhukov, S. (Eds), Central Asia: The Challenges of Independence, M.E. Sharpe, Armonk, NY, pp. 208-33.

Trushin, E. (1998b), "Uzbekistan: problems of development and reform in the agrarian sector", in Rumer, B. and Zhukov, S. (Eds), Central Asia: The Challenges of Independence, M.E. Sharpe, Armonk, NY, pp. 259-91.

Veduta, E.N. (1998), Government's Economic Strategies, Delovaya Kniga, Moscow, (in Russian).

von Mises, L. (1981), Socialism. An Economic and Sociological Analysis, Liberty Classics, Indianapolis, IN (originally published in 1936).

Weder, B. (2001), Model, Myth, or Miracle? Reassessing the Role of Governments in the East Asian Experience, UN University Press, Tokyo.

Wellisz, S. (1997), "Inflation and stabilization in Poland", in Blejer, M.I. and Škreb, M. (Eds), Macroeconomic Stabilization in Transition Economies, Cambridge University Press, Cambridge, pp. 157-71.

Winckler, G. (Mod.) (1992), "Central and Eastern Europe: roads of growth”, papers presented at a Seminar held in Baden, Austria, April 15-18, 1991, IMF, Washington, DC.

Wolf, C. Jr (1994), Markets or Governments? Choosing between Imperfect Alternatives, MIT Press, Cambridge, MA.

Wolfenson, J.D. (1999), “A proposal for a comprehensive development framework”, discussion draft, The World Bank, Washington, DC.

World Bank (1993), The East Asian Miracle. Economic Growth and Public Policy, Oxford University Press, New York, NY.

World Bank (1996), From Planning to Market. A Report on International Development - 1996, Oxford University Press, Oxford.

World Bank (1999), Global Economic Prospects and the Developing Countries. Beyond Financial Crisis, The World Bank, Washington, DC. 
Yarbrough, B.V. and Yarbrough, R.M. (1997), The World Economy: Trade and Finance, The Dryden Press, Fort Worth, TX.

Yevstigneeva, L. and Yevstigneev, R. (1999), "Where do reforms lead to? (Reflections on a J. Stiglitz essay)”, Voprosy ekonomiki, No. 9, pp. 4-18 (in Russian).

Zhukov, S. (1997), "Kazakhstan, Kyrgyzstan, Uzbekistan in social/economic structures of the modern world", Mirovaya ekonomika i mezhdunarodnye otnoshenija., No. 3, pp. 45-60 (in Russian).

Zhukov, S. (2000), "Adapting to globalization", in Rumer, B. (Ed.), Central Asia and the New Global Economy, M.E. Sharpe, Armonk, NY, pp. 149-73.

Zukowski, R. (1996), "Transformation crisis in post-Socialist countries: patterns and causes", International Journal of Social Economics, Vol. 23 No. 10/11, pp. 279-96.

\section{Further reading}

Luttwak, E. (1999), Turbo-Capitalism. Winners and Losers in the Global Economy, Harper Perennial, New York, NY.

Kolodko, G.V. (Ed.) (2000), “The shock therapy vs gradualism: ten years later”, From Shock to Therapy. Political Economy of Post-Socialist Transformations, ZAO Zhurnal Ekspert, Moscow, pp. 4-8 (in Russian).

\section{Post-Communist economic transition}

